\title{
The development of a municipal water conservation and demand management strategy and business plan as required by the Water Services Act, South Africa
}

\author{
WA Wegelin and HE Jacobs* \\ Hydraulics and Water Services, Department of Civil Engineering, Stellenbosch University, Private Bag X1, Matieland 7602, South Africa
}

\section{ABSTRACT}

\begin{abstract}
The implementation of water conservation and water demand management (WC/WDM) at municipal level has been inadequate for many years, despite South Africa being one of the driest countries in the world. This could be attributed to a lack of planning, and not realising the consequences and potential benefits of water restrictions. Many South African municipalities do not have a WC/WDM strategy and business plan although many books, publications and software packages have been produced to assist water supply managers. Most of the existing strategies are also vague and of little value, and the municipalities do not have the necessary financial, technical and institutional capacity to support such a strategy. Municipalities often fail to realise that most WC/WDM activities will pay for themselves and that financial institutions will fund these projects if a proper business case could be compiled. Ironically municipalities have complained that they are unable to obtain funding while most financial institutions complain that they cannot find bankable projects because of the poor quality of the applications and strategies. This guideline provides a simple and pragmatic approach to the development of a WC/WDM strategy and business plan which will enable municipalities to plan, obtain funding, implement and ensure the overall sustainability of water resources in the municipality and the country as a whole.
\end{abstract}

Keywords: water conservation, demand management

\section{INTRODUCTION}

The Water Services Act, Act 108 of 1997 (RSA, 1997a) stipulates that all spheres of government must provide water supply services in an efficient, equitable and sustainable manner. The Act also requires municipalities that have been given Water Services Provider status to provide measures to promote water conservation and demand management which should be included in their Water Conservation and Water Demand Management (WC/WDM) strategy and business plan and Water Services Development Plan (WSDP).

In his 2010 State of the Nation Address, His Excellency JG Zuma, President of the Republic of South Africa, stated, 'We are not a water rich country. Yet we still lose a lot of water through leaking pipes and inadequate infrastructure. We will be putting in place measures to reduce our water loss by half by 2014 .

Although the target for reducing water losses has been set, activities at municipal level to reach this goal have been limited (McKenzie et al., 2012) which could be attributed to a lack of planning, and not realising the consequences and potential benefits of WC/WDM. Although various books, manuals and publications (e.g. Hunt et al., 1998; White, 1998; American Water Works Association, 2006; American Water Works Association, 2010) as well as software packages (McKenzie and Bhagwan, 2000) have been produced over the years to assist water supply managers to develop strategies that address the

This paper was originally presented at the 2012 Water Institute of Southern Africa (WISA) Biennial Conference, Cape Town, 6-10 May 2012.

* To whom all correspondence should be addressed.

棌 +27 21 808-4059; e-mail: hejacobs@sun.ac.za various WC/WDM issues, many South African municipalities do not have a WC/WDM strategy. The Department of Water and Environmental Affairs (DWA) reported that many of the existing strategies are vague and of little value (DWA, 2011). Many municipalities have limited financial, technical and institutional capacity to prepare a WC/WDM strategy.

\section{APPROACH}

The methodology for this study was developed as part of the so-called 'Large Bulk Water Supply Reconciliation Strategy Study' for the Vaal River system (DWAF, 2006; DWAF, 2009) conducted by the national Department of Water Affairs and Forestry (DWAF, now DWA - Department of Water Affairs). The purpose of the DWAF study was to develop a strategy for meeting the growing water requirements of the industrial and urban sectors that are served by the Integrated Vaal River System (IVRS). WC/WDM has a major influence on future water demand projections and therefore formed an integral part of the study (DWA, 2010). The methodology developed during this study has subsequently been refined in a few case studies (DWA, 2012) as part of the DWA Rapid Response Programme and interactions with the DWA and municipalities.

The research method could be described by the following steps: (i) problem identification and description; (ii) literature review of existing methodologies (iii) perform status quo and constraints assessment through SWOT analysis and quantitative scorecard at municipal and regional workshop level, (iv) develop savings model (v) prepare guideline towards the development of a WC/WDM strategy and business plan, and (vi) prepare templates through various case studies to act as a presentable and user-friendly interface. 


\section{RELEVANCE}

It is clear from various WC/WDM workshops held throughout the country as part of this research, and attended by 147 munic ipalities and other government organisations, that there is an urgent need for a more guided approach, through the development of templates that will assist municipalities and which will be endorsed by the major role players in the water industry.

National government departments have also expressed their frustration with the lack of progress and quality of WC/WDM strategies and have noted that it does not address their needs. In this regard, the major role players such as the Department of Water Affairs (DWA), National Treasury, provincial government, local government and the South African Local Government Association (SALGA) all need to be part of the process in order to ensure that there is a clear direction on what is required and how it will be achieved (DWA, 2011).

Municipalities often fail to realise that many WC/WDM activities could pay for themselves and that financial institutions will fund these projects if they can compile a proper business case. Most municipalities engaged during this investigation complained that they are unable to obtain funding while conversely financial institutions complain that they cannot find viable projects because of the poor quality of the applications and strategies. The strategy and business plan should include the development of a business case which could be presented to a financial institution for funding (DWA, 2011).

This paper presents a guideline towards the development of a WC/WDM strategy and business plan in a presentable format which can be used by municipalities to obtain funding. The guideline addresses the objectives, methodology, information required and issues which need to be considered.

\section{DEFINITIONS}

The DWA has adopted the generic term of 'Water Conservation and Water Demand Management (WC/WDM)' although these terms have been defined independently in the Water Services Sector Strategy (DWAF, 2004) as:

- WC is the minimisation of loss or waste, the care and protection of water resources and the efficient and effective use of water.

- WDM is the adaptation and implementation of a strategy by a water institution or consumer to influence the water demand and usage of water in order to meet any of the following objectives: economic efficiency, social development, social equity, environmental protection, sustainability of water supply and services and political acceptability.

From a scientific viewpoint the DWA-definitions may be considered vague. A more detailed description of the terminology was provided by Butler and Memon (2006). The following is a brief review of the notation, promoted by the International Water Association (IWA), although it was not adopted in this study:

- Water conservation - 'doing less with less' and is particularly applicable in drought scenarios and water restrictions (example: take shorter showers; do not irrigate the lawn)

- Water efficiency - 'doing the same (or more) with less' (example: fix leaks; hydraulically efficient toilet pan and cistern design)

- Water sufficiency - 'enough is enough' (example: automatic shut-off of taps; dual flush toilets; careful garden watering)

- Water substitution - 'replace water with something else, say air' (example: waterless urinals; vacuum drainage; dry cleaning)

- Water reuse (example: greywater reuse on-site; shared bath water; groundwater abstraction on-site)

Some countries (particularly North America) prefer to use 'demand side management' (DSM) instead of WDM, which complicates matters even further regarding a clear definition. The South African electricity sector uses DSM for demand management related issues, while the country's local electricity provider ESKOM uses 'integrated demand management'. Gumbo et al. (2003) noted that WDM is not possible in the absence of information management and; water information management' (WIM) was subsequently defined by Jacobs (2008).

For purposes of this study the terms Water Conservation and Water Demand Management (WC/WDM) as recommended by DWA were adopted.

\section{CURRENT CONSTRAINTS}

Constraints in terms of WC/WDM application were considered insurmountable by Mwendera et al. (2003), who concluded that there was no simple answer for achieving the stated goals. The most notable problems, or perceived problems, with $\mathrm{WC} / \mathrm{WDM}$ strategies and projects currently in place at municipalities were identified as part of this research. Constraints in terms of WC/WDM were described comprehensively in earlier reports (Hazelton et al., 2002; Arntzen, 2003), and a full review is beyond the scope of this text. Some constraints noted during this study include the following:

- Detailed WC/WDM strategies are expected to be associated with huge budgets which can often not be funded from internal sources and very few municipalities are able to obtain external funding, which results in very detailed studies often becoming dormant. This study recommends budgeting smaller amounts that are within the means of the municipality or grant funding to be targeted once a proper business plan can be developed within the means of the municipality.

- McKenzie et al. (2012) show that $44 \%$ of municipalities cannot provide a water balance, with the result that $\mathrm{WC} /$ WDM projects are identified and implemented based on perceptions without proper water information management, such as a baseline volume. The results from these projects are often disappointing, and the projects are not achieving their goals, as the scale of the perceived problem is often much lower than originally thought or the wrong intervention was undertaken. This study recommends that the initial strategy should focus on obtaining proper WIM which should then direct the future of the strategy.

- There is a tendency towards 'analysis paralysis' and defining water losses to the third decimal. Huge amounts of money are often spent on developing strategies and analysing systems when the most basic activities, such as bulk metering, are not even performed properly by the municipality. The same amount of money could have been used to install bulk meters with much greater benefit to the municipality.

- The non-financial census of municipalities conducted by Statistics South Africa (SSA, 2011) suggests a vacancy rate of $25 \%$ and $20 \%$ in municipal water and finance departments, respectively. In some municipalities vacancy rates are as high as $50 \%$ which means it is unrealistic to expect the implementation of elaborate WC/WDM plans if there 

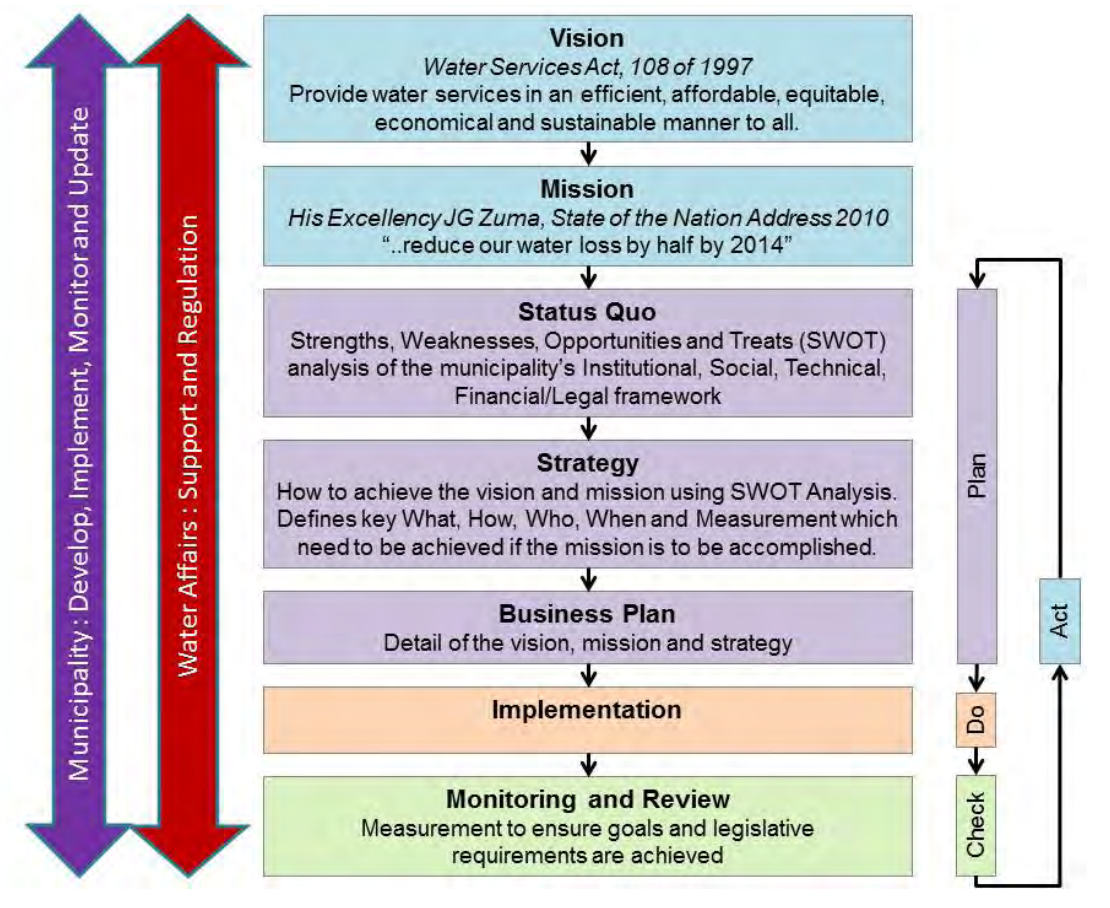

are no staff members to undertake the work. This study recommends that WC/WDM activities are undertaken that are within the capacity the municipality. Projects which cannot be sustained should be avoided.

- Municipalities often indicate lack of political support (DWA, 2011) as a main stumbling block towards implementing WC/WDM. Although this might be the case, there is also a lack of the practice of presenting WIM to politicians based on facts and figures and discussing these on a monthly basis.

- Technical and finance departments work in silos while they should be supporting each other in resolving metering and billing errors.

\section{STRATEGY AND BUSINESS PLAN DEVELOPMENT}

The research promotes the development of a high level, dynamic strategy which requires less initial funding and develops with time, as opposed to very detailed strategies with huge budgets which often do not get implemented. The proposed strategy and business plan development methodology is shown in Fig. 1.

The proposed methodology suggests following a conventional business strategy model of defining the vision and mission of the organisation. In order to address the vision and mission, a good understanding of the status quo is required. Once the organisation is clear on where they are and where they want to be, a strategy and business can be developed to ensure the goals are achieved. Monitoring and review should be ongoing and the strategy and business plan adjusted to ensure that goals are achieved. Details on each component are discussed in the following sections.

\section{Vision}

The vision describes the purpose of the organisation and is a 'just achievable' wish or dream. The vision is not measureable or detailed and remains constant. All municipalities have the same vision, as described in the Water Services Act, 'to provide water services in an efficient, affordable, equitable, economical and sustainable manner to all consumers or potential consumers in its area of jurisdiction' (RSA,1997; section 11 (1)).

\section{Mission}

The mission of an organisation is the key actions to be taken to achieve the vision. The mission is measurable and describes what the organisation as a whole will achieve and the overall time scale. In his 2010 State of the Nation Address, His Excellency President JG Zuma, stated the mission for all municipalities, which is to reduce water loss by half by 2014 .

\section{Status quo}

Before a strategy and business plan can be developed, it is important to have a proper understanding of the status quo. To obtain a proper understanding of the status quo, it is recommended to perform a 'strengths, weaknesses, opportunities and threats' (SWOT) analysis of the institutional, technical, financial, legal and social components of the municipal water business. The SWOT analysis should be combined with an analysis of key performance indicators such as non-revenue water, water losses and unit consumption.

\section{Strategy}

The strategy describes the key milestones required to achieve the vision and mission. The strategy should describe what is required, how, by whom and by when. It should also include the agreed measures of success.

\section{Business plan}

The business plan provides the detail of the vision, mission and strategy. The business plan should address water supply and demand, budgets, funding, cash flows, cost benefits, roles and responsibilities, risks and address legislative and regulatory requirements.

\section{Implementation}

The municipality is responsible for obtaining funds, appointing professional service providers and contractors, quality and budget control and achieving timelines. 


\begin{tabular}{|l|l|l|}
\hline SWOT Analysis & $\begin{array}{l}\text { External - Opportunities } \\
\text { Positive external conditions } \\
\text { which one does not control and } \\
\text { which one could take } \\
\text { advantage of }\end{array}$ & $\begin{array}{l}\text { External - Threats } \\
\text { Negative conditions which } \\
\text { one does not control but the } \\
\text { effects of which one could } \\
\text { minimise }\end{array}$ \\
\hline $\begin{array}{l}\text { Internal - Strengths } \\
\text { Positive aspects under one's control } \\
\text { and on which one may wish to } \\
\text { capitalise }\end{array}$ & $\begin{array}{l}\text { Strengths and Opportunities } \\
\text { (SO) - Strategies that use } \\
\text { strengths to maximise } \\
\text { opportunities }\end{array}$ & $\begin{array}{l}\text { Strengths and Threats (ST) - } \\
\text { Strategies that use strengths } \\
\text { to minimise threats }\end{array}$ \\
\hline $\begin{array}{l}\text { Internal - Weaknesses } \\
\text { Negative aspects under one's } \\
\text { control (to a large extent) which } \\
\text { one could plan to improve }\end{array}$ & $\begin{array}{l}\text { Weaknesses and Opportunities } \\
\text { (WO) - Strategies that minimise } \\
\text { weaknesses by taking } \\
\text { advantage of opportunities }\end{array}$ & $\begin{array}{l}\text { Weaknesses and Threats (WT) } \\
\text { - Strategies that minimise } \\
\text { weaknesses and avoid threats }\end{array}$ \\
\hline
\end{tabular}

Figure 2

SWOT analysis to

develop the strategy

\section{Monitoring and review}

To ensure the goals of vision and mission are achieved, it is important to continuously measure, monitor and review progress in terms of achieving the set targets. Municipalities must also use this information to provide feedback to the DWA in terms of the regulatory framework.

Once certain goals have been achieved, the status quo will change, which again will change the strategy and business plan. There should, therefore, be a continuous process of plan, do, check and act.

\section{Role players}

The two key role players during the development, implementation and monitoring of a WC/WDM strategy are the municipality and the DWA. In terms of the Water Act (RSA, 1997b), the municipality has the responsibility to provide water services in an efficient, affordable, equitable, economical and sustainable manner to all consumers or potential consumers in its area of jurisdiction, while the DWA is ultimately responsible for national policy, a regulatory framework and ensuring that other institutions are effectively fulfilling their roles and responsibilities.

\section{STRATEGY AND BUSINESS PLAN MODEL}

Utilising the methodology described in the previous section, a WC/WDM strategy and business plan should include the sections described below and could be viewed as a generic framework for such a document.

\section{Background}

This section provides details on the methodology, contact persons, terminology and potential sources of information.

\section{Base information}

Informed decisions cannot be made without some basic information. This section requires information on the population, households, metered and un-metered connections, length of mains, system input volume, authorised consumption, and so forth, which is used throughout the strategy to identify key problem areas and performance indicators.

\section{Quantitative scorecard}

The quantitative scorecard captures the results from the SWOT analysis and should direct the strategy. It is recommended that the analysis is performed from the perspective of the Water Services Department.

The SWOT analysis is performed by completing a list of questions on the following:

- Institutional/legal framework: the objective of this section is to obtain an understanding of the institutional capacity and capabilities, potential for public-private partnerships and legal framework in terms of policies, bylaws and compliance.

- Social framework: the objective of this section is to obtain an understanding of the consumer profile in terms of knowledge, attitudes and perceptions regarding water conservation.

- Technical/management framework: the objective of this section is to obtain an understanding of the water supply characteristics with regards to level of service, metering, operational problems and management information systems.

- Financial framework: the objective of this section is to obtain an understanding of the finance department and their capacity and capability to perform metering and billing.

Having completed the SWOT analysis, the next objective is to develop the strategy by minimising weaknesses and threats and maximising strengths and opportunities as shown in Fig. 2.

\section{Integrated water resource planning}

Each water services authority (WSA) should have a clear understanding of their system's demand versus the supply capability and when additional resources should be developed. The WSA should also have a clear understanding on what impact WC/WDM could have on the projected demand and the overall viability of the water services. Figure 3 presents the water supply and demand balance diagram.

\section{Water balance calculations}

The IWA water balance, adjusted for South African conditions to allow for free basic water, should form the basis of an estimate into the potential savings that can be achieved. The methodology is fully described in Seago et al. (2007). Figure 4 shows the IWA water balance with the last column showing the potential savings that can be achieved from WC/WDM.

The descriptions for each of the different categories are as follows:

- Billed and recovered: For this volume of water, either metered or unmetered, payment is received for the sale thereof.

- Allowable free basic: This volume of water, $6 \mathrm{k} \ell$ per household per month, is supplied at no cost to all households.

- Potential billed and recoverable: This is a volume of water that is currently either metered or unmetered; however, the customer is not billed and, therefore, does not pay. It is unlikely that the current water usage will drop, should the customer suddenly be billed, and therefore its volume does not form part of the physical savings. It would merely be a financial income to the WSA should billing start. 


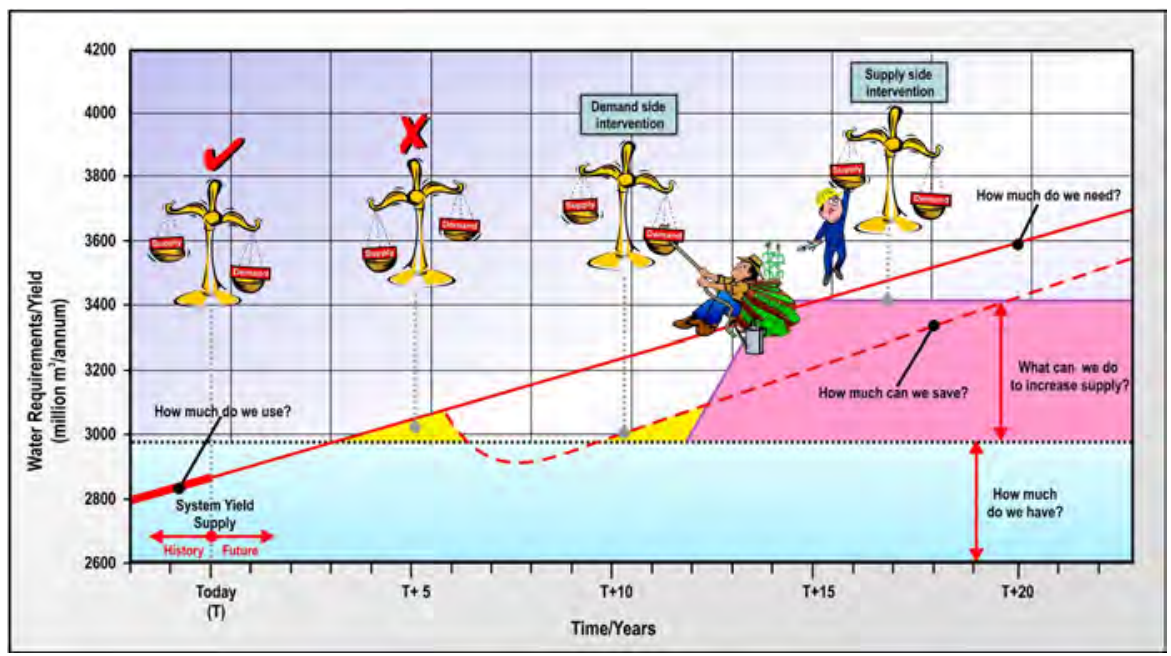

Figure 3

Water supply and demand balance diagram (WRP, 2012)

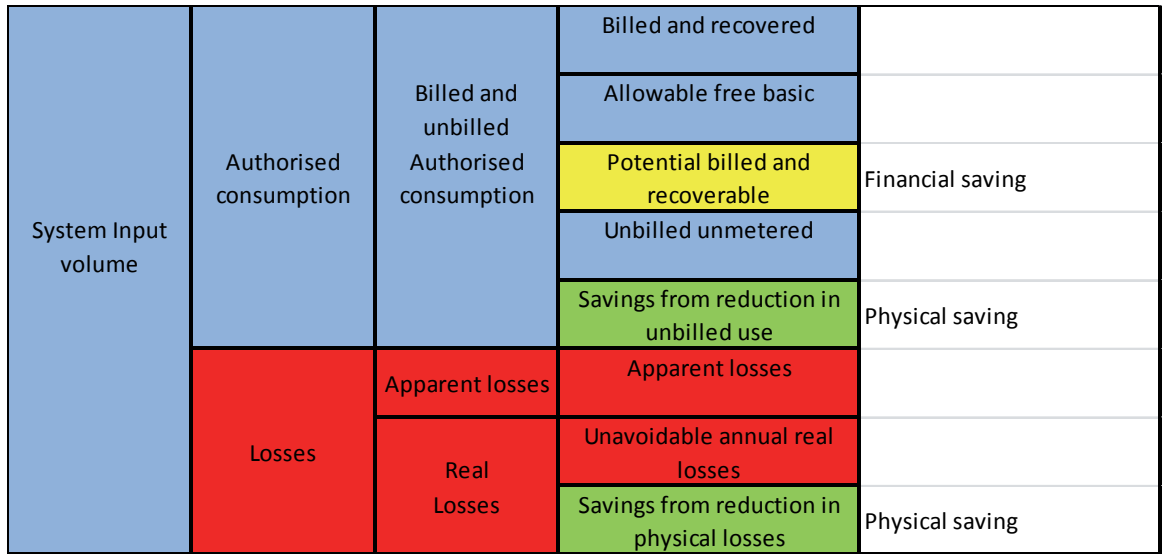

Figure 4

Breakdown of IWA water balance and potential WC/WDM savings (from Seago et al., 2007)

Unmetered industries typically fall into this category.

- Unbilled unmetered: This component of unbilled authorised consumption will also not reduce as a result of proper billing and/or income recovery since it is based mainly on water used for fire fighting and mains flushing. This component is normally small in most systems.

- Apparent losses: The apparent losses are based on an assessment of the levels of illegal connections in the system as well as the age of the meters and quality of the water. This approach is subjective to some extent and dependent on the in-depth knowledge of the system.

- Unavoidable Annual Real Losses (UARL): This volume of water is calculated from the standard UARL equation and is a function of length of mains, number of service connections and average operating pressure.

\section{Savings}

The overall water savings as a result of interventions are made up of a combination of the lower consumption by users that are limited to the allowable free basic use and the savings from a reduction in physical losses. The balance between these two portions of savings will differ between systems. The savings will therefore reduce the non-revenue water by turning it into revenue water or reduce the total consumption.

\section{WC/WDM potential assessment}

Knowing the location and extent of the water losses in the distribution system, the next section should identify the potential interventions to reduce the losses and by how much.
Assessing the potential savings is probably one of the most difficult tasks, as systems vary and it is difficult to predict the savings.

Comparing the estimated savings from the water balance with the potential savings that could be achieved through various interventions provides a good indication of the potential savings. In each case, these two values should be close to each other, in order to establish a realistic potential saving, as shown in Fig. 5. Using an arbitrary value of between $10 \%$ and $20 \%$ potential saving is not recommended.

Table 1 provides guidelines on the potential saving which could be achieved based on various WC/WDM projects that have been implemented over the past few years. The figures are a guideline and difficult to define as every system is different; the figures should be confirmed during the monitoring and review process.

\section{Aspects to consider}

In order to make a realistic estimate of potential savings, it is important to have a proper understanding of technical, institutional, social, legal and financial constraints of the system.

These issues include:

- Loss of skilled resources and expertise in the water sector municipalities are run by skeleton staff and, with the lack of skilled resources, there is limited time to undertake planning and most time is spent on crisis management.

- Supply-minded thinking and system operation - planning and operations staff have, for a very long time, increased the supply from new sources when the demand increased, 


\begin{tabular}{|c|}
\hline Potential savings from water balance calculation \\
\hline Billed and recovered \\
\hline Allowable free basic water \\
\hline Potential billed and recoverable \\
\hline Unbilled unmetered \\
\hline Savings from reduction in unbilled use \\
\hline Apparent losses \\
\hline UARL \\
\hline Savings from reduction in physical losses \\
\hline
\end{tabular}

$=$\begin{tabular}{|c|}
\hline Potential savings from WDM interventions \\
\hline Metering and billing \\
\hline Pressure reduction \\
\hline Retrofit and romoval of wasteful devices \\
\hline Mains replacement \\
\hline Active leakage control \\
\hline Bylaws and enforcement \\
\hline Sectorising and bulk metering \\
\hline Community awareness \\
\hline
\end{tabular}

Figure 5 Savings versus interventions

\begin{tabular}{|c|c|}
\hline \multicolumn{2}{|r|}{$\begin{array}{c}\text { TABLE } 1 \\
\text { Potential savings from various WC/WDM interventions }\end{array}$} \\
\hline Intervention & Potential saving \\
\hline Pressure management & $\begin{array}{l}\text { Various pressure management projects have shown an expected reduction in minimum night } \\
\text { flow of between } 15 \text { and 30\%. The PRESMAC model (McKenzie et al., 2000) can also be used to } \\
\text { calculate the estimated savings. }\end{array}$ \\
\hline $\begin{array}{l}\text { Active and passive leakage } \\
\text { control }\end{array}$ & $\begin{array}{l}\text { The SANFLOW model (McKenzie et al., 2000) suggests the average burst runs at } 1.6 \mathrm{~m}^{3} / \mathrm{h} \text {. } \\
\text { With an understanding of the estimated number of bursts and the repair time the potential } \\
\text { savings from bursts and background leakage can be calculated. }\end{array}$ \\
\hline Retrofitting & $\begin{array}{l}\text { A volume of } 2 \text { to } 15 \mathrm{k} \ell \text { per property per month can be saved, with up to } 50 \mathrm{k} \ell \text { per property per } \\
\text { month in exceptional areas like Soweto. It is important to have a good understanding of the } \\
\text { current and expected consumption before estimating the potential savings. }\end{array}$ \\
\hline $\begin{array}{l}\text { Improved management through } \\
\text { sectorisation, water balance } \\
\text { calculations and response time }\end{array}$ & $\begin{array}{l}\text { Improved management such as sectorisation, bulk metering, reaction time to leaks and over- } \\
\text { flowing reservoirs could result in a reduction of } 1 \% \text { to } 5 \% \text { in overall consumption. }\end{array}$ \\
\hline $\begin{array}{l}\text { Installation of water-efficient } \\
\text { devices }\end{array}$ & $\begin{array}{l}\text { Installation of low-flow shower heads, dual-flush toilets and other water-efficient devices can } \\
\text { reduce water consumption by } 10 \text { to } 20 \% \text { depending on the number of installations. }\end{array}$ \\
\hline Water-wise gardening & $\begin{array}{l}\text { Garden watering constitutes } 30 \text { to } 50 \% \text { of domestic consumption and can be easily reduced } \\
\text { through water-wise gardening practices. }\end{array}$ \\
\hline
\end{tabular}

instead of addressing the demand. It may be very difficult, and will take a long time, to change this attitude.

- Lack of system understanding - the system operation is not documented and municipalities have experienced major staff turnover in recent years, with many posts often not refilled. Zone boundaries are compromised; low pressure problems in zones are incorrectly addressed through opening of pressure-reducing valves although the problem may be related to unauthorised closed valves.

- Lack of water information management - municipalities do not have proper record keeping and management information systems to monitor supply and demand trends.

- Lack of funds - the financial situation of municipalities has deteriorated to such an extent that they rely on grants and unsecured loans with very little income generated from metering and billing. They can also not apply for funding, as they are not credit worthy.

- Lack of maintenance - control valves and water meters are not maintained. Very few municipalities can provide details on control valves and bulk meters, such as size, model, make, settings, historical readings, service dates, etc. These points are often critical in the efficient operation of the system.

- Payment for services - payment for water services is a contentious issue and still not accepted in many parts of the country. This situation is exacerbated by poor service delivery from municipalities, which includes lack of metering, inaccurate billing and intermittent supply.

- Social responsibility - in many parts of the country water is still considered a gift from God in terms of social perspective and it is not understood why water should be paid for. This lack of understanding often leads to water wastage and inefficient use.

\section{APPLICATION OF THE DEVELOPED METHODOLOGY}

The results from the IVRS reconciliation study have now been monitored for 8 years (2004-2012) and the projected use seems realistic and achievable. Figure 6 shows the demand curves for City of Johannesburg, which has been following the 'high population no WDM' curve. The 'high population no WDM' curve is a function of the projected population growth, level of service, effect of HIV/AIDS, economic growth and other factors. The 'high population with WDM' curve shows the potential effect of WC/WDM should it be implemented successfully over 5 years. City of Johannesburg still supports the projection but has been unable to achieve the target, mainly due to the problems experienced with the allocation of funds and the stopping of Operation Gcin'amanzi, which was targeted at reducing the excessive leakage in Soweto.

Figure 7 shows the demand curves for City of Tshwane, which has been able to exceed the projected savings. The considerable drop in demand in 2008 was because of very aggressive water tariff setting and other WC/WDM interventions. Figure 7 also shows that the potential saving in City of Tshwane is less than in City of Johannesburg as the two municipalities have different levels of efficiency and water losses.

The methodology used seems practical and provides a firstorder assessment of the potential saving through WC/WDM. 


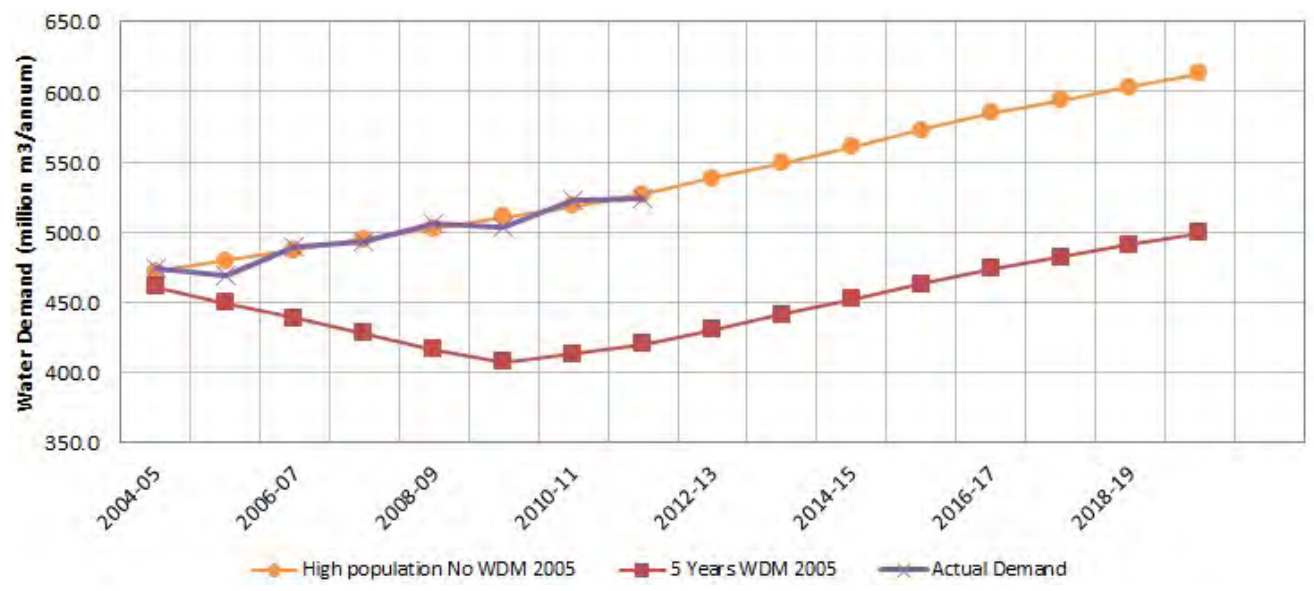

Figure 6

City of

Johannesburg

demand

projection

with and

without

WC/WDM

versus actual

demand

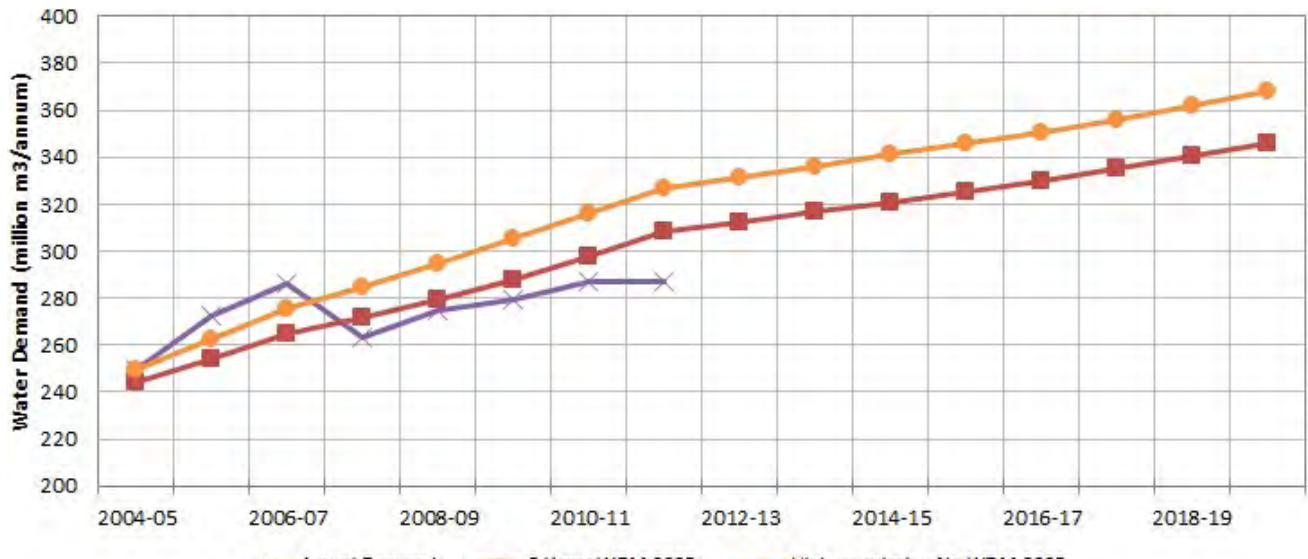

Figure 7

City of Tshwane demand projection with and without WC/WDM versus actual demand

The strategy and business plan methodology presented here is currently being developed for another 30 local municipalities across the country.

\section{CONCLUSION}

A considerable number of issues need to be taken into consideration when assessing the potential savings from WC/WDM. Arbitrary savings of $10 \%$ to $40 \%$ with no real scientific evaluation of the water distribution system, or targeting of international benchmarks, might not be achievable and realistic for developing countries. It was noted as part of this investigation that municipalities often simply select such arbitrary targets without any scientific basis.

The continuation of current, and the initiation of further, $\mathrm{WC} / \mathrm{WDM}$ measures are essential to maintain a positive water balance in parts of the country over the next 10 years (DWA 2010). The potential savings will ensure that the risk of drought curtailments is reduced.

The development of a WC/WDM strategy and business plan is essential to ensure the sustainability of a municipal water supply system. The development of a high-level strategy has the benefit that it could be developed with limited budget, and updated and implemented over time. The WC/WDM strategy and business plan guideline provides the following components:

- Clear objectives in terms of reduced water losses, increased revenue and sustainable water supply

- Current available resources and capacity of the system

- Projected water demand and implications if the water demand exceeds the capacity of the system
- Realistic quantification of potential savings and impact on future water demand projections

- Identification of key interventions with budgets, timelines, benefits, and cost-benefit ratios

- Indirect benefits such as job creation, community awareness and responsible users

- Benefit to the municipality in terms of increased revenue and sustainability

- Institutional arrangements required to achieve these objectives

- Development of a business case which can be presented to a financial institution for funding

This is the first report of a generic procedure that could be used to develop a municipal WC/WDM strategy and business plan in line with South African water demands. Practical application of the methodology in a few industrial and urban sectors that are served by the IVRS has shown that it can be a valuable tool for managing demand and could form the basis of future WC/WDM business plans.

\section{REFERENCES}

AMERICAN WATER WORKS ASSOCIATION (2010) Water Conservation Guidebook for Small-and Medium-Sized Utilities. American Water Works Association, Denver.

AMERICAN WATER WORKS ASSOCIATION (2006) Manual of Water Supply Practices - M52, First Edition. Water Conservation Programs: A Planning Manual. American Water Works Association, Denver.

ARNTZEN J (2003) Incorporation of Water Demand Management in National and Region Water Policies and Strategies. A report 
prepared for IUCN South African Office, WDM Southern Africa Project Phase 2, Centre for Applied Research, Botswana-IUCN, South Africa Office, June 2003.

BUTLER D and MEMON FA (2006) Water Demand Management. IWA Publishing, London.

DWA (DEPARTMENT OF WATER AFFAIRS AND FORESTRY, SOUTH AFRICA) (2004) The Water Conservation and Water Demand Management Strategy for the Water Services Sector, South Africa, 2004. Department of Water Affairs and Forestry, Pretoria.

DWA (DEPARTMENT OF WATER AFFAIRS, SOUTH AFRICA) (2010) Vaal River System Reconciliation Strategy: Strategy Steering Committee Gauteng Municipalities Water Conservation and Water Demand Management Progress Reports. March/October 2010. Department of Water Affairs and Forestry, Pretoria.

DWA (DEPARTMENT OF WATER AFFAIRS, SOUTH AFRICA) (2010) Integrated Water Resource Planning for South Africa. October 2010. Department of Water Affairs, Pretoria.

DWA (DEPARTMENT OF WATER AFFAIRS, SOUTH AFRICA) (2011) Report on WC/WDM Training Workshops under the Masibambane III. February 2011. Department of Water Affairs, Pretoria.

DWA (DEPARTMENT OF WATER AFFAIRS, SOUTH AFRICA) (2012) Development of high level WC/WDM strategies and business plans for various municipalities under the Rapid Response Programme. Department of Water Affairs, Pretoria.

DWAF (DEPARTMENT OF WATER AFFAIRS AND FORESTRY, SOUTH AFRICA) (2006) Vaal river system: Large bulk water supply reconciliation strategy: First stage reconciliation strategy. December 2006. Department of Water Affairs and Forestry, Pretoria.

DWAF (DEPARTMENT OF WATER AFFAIRS AND FORESTRY, SOUTH AFRICA) (2007) Potential savings through WC/WDM in the Upper and Middle Vaal water management areas. May 2007. Department of Water Affairs and Forestry, Pretoria.

DWAF (DEPARTMENT OF WATER AFFAIRS AND FORESTRY, SOUTH AFRICA) (2009) Vaal River system: Large bulk water supply reconciliation strategy: Second stage reconciliation strategy. March 2009. Department of Water Affairs and Forestry, Pretoria.

GUMBO B, JUIZO D and VAN DER ZAAG P (2003) Information is a prerequisite for water demand management: experiences from four cities in Southern Africa. Phys. Chem. Earth 28 827-837.
HAZELTON D, NKHUWA D AND ROBINSON P (2002) Overcoming constraints to the implementation of WDM in Southern Africa: Vol.1 Synthesis report; Vol. 4 case studies, advocacy and implementation tools. IUCN, Pretoria.

HUNT JB, MCDEVITT W and HUNT G (1998) Water Efficiency Manual for Commercial, Industrial and Institutional Facilities. A joint publication of the Division of Pollution Prevention and Environmental Assistance and Division of Water Resources of the North Carolina Department of Environment and Natural Resources, and the Land-of-Sky Regional Council - WRATT Program, August 1998.

JACOBS HE (2008) Residential water information management. S. Afr. J. Inf. Manage. 10 (3) 1.

McKENZIE RS and BHAGWAN JN (2000) Managing unaccounted for water in potable water distribution systems: recent software developments through the WRC. The Official Journal of the Institution of Municipal Engineers (January) 53-58.

McKENZIE RS, SIQALABA ZN and WEGELIN WA (2012) The state of non-revenue water in South Africa. WRC Report No. TT 522/12. Water Research Commission, Pretoria.

MWENDERA EJ, HAZELTON D, NKHUWA D, ROBINSON P, TJIJENDA K and CHAVULA G (2003) Overcoming constraints to the implementation of water demand management in southern Africa. Phys. Chem. Earth 28 761-778.

RSA (REPUBLIC OF SOUTH AFRICA) (1997) Water Services Act, Act 108 of 1997. Government Gazette No. 18522. 19 December 1997

RSA (REPUBLIC OF SOUTH AFRICA) (1998) National Water Act, Act 36 of 1998. Government Gazette No. 19182. 26 August 1998.

SEAGO C, BHAGWAN J and McKENZIE R (2004) Benchmarking leakage from water reticulation systems in South Africa. Water SA 30 (5) 25-32.

SSA (STATISTICS SOUTH AFRICA) (2011) P9115 - Non-Financial Census of Municipalities. June 2011. Statistics South Africa, Pretoria.

WHITE S (1998) Wise water management - a demand management manual for water utilities. Water Services Association of Australia, Research Report No. 86, November 1998.

WRP (WRP ENGINEERS) (2012) Second African Water Leakage Summit and WDM Workshop, 29-31 August 2012, Camps Bay, South Africa. 